(2014) 2 NIBLeJ 4

\title{
Social Policy and Insolvency: Struggles towards Convergence
}

\author{
Jennifer L.L. GANT*
}

\section{Introduction: Cooperation, Coordination and Conflict}

1 The cooperation of European countries in matters of insolvency has a long history. It has been a 40 year project within the European Union, ${ }^{1}$ evolving in complexity and increasing in cooperation as the EU has expanded and changed. ${ }^{2}$ The culmination of this cooperation was the EU Insolvency Regulation ${ }^{3}$ which deals with the coordination of cross-border insolvency between member states. In 2012, INSOL Europe ${ }^{4}$ proposed amendments ${ }^{5}$ to the EIR, aimed at furthering its proper functioning by amending substantive aspects and improving technical rules. Among the fundamental issues to be resolved was the ease with which companies can "forum shop" among member states to identify a jurisdiction providing the most advantageous environment to commence insolvency proceedings. However, goal of reducing forum shopping overall is not helped by the existence of divergent rules of employment protection among the member states.

2 Underpinned by traditionally opposing socio-political values, the juxtaposition of insolvency law and employment protection is difficult to reconcile. However, in these times following the financial crisis and its slow recovery, business failures

\footnotetext{
* Jennifer Gant is a doctoral researcher at the Nottingham Law School. This article is based on presentations given at the Society of Legal Scholars PhD Conference in Edinburgh, Scotland on 2 September 2013 under the title "European Insolvency and Social Policy: Harmonisation Woes" and at the INSOL Europe Academic Forum Annual Conference in Paris, France on 26 September 2013 under the title "Social Policy and the Reform of the European Insolvency Regulation".

${ }^{1}$ Hereafter referred to as the "EU".

${ }^{2}$ See P. Omar, European Insolvency Law (2004, Ashgate, Aldershot), at 49.

Council Regulation (EC) No. 1346/2000 of 29 May 2000 on insolvency proceedings (OJ 2000/L160/1) (hereafter referred to as the "EIR").

${ }^{4}$ INSOL Europe is an organisation of professionals and academics within the European Union specialising in insolvency and business reconstruction.

${ }_{5}$ Proposals are set out in R. van Galen et al., Revision of the European Insolvency Regulation: Proposals by INSOL Europe (2012, INSOL Europe, Nottingham).

${ }^{6}$ Ibid., at 17: “...the transferring of assets or judicial proceedings from one Member state to another seeking to obtain a more favourable legal position...".
} 
and unemployment are both at the forefront of economic concerns. The EU has applied itself to the intersection of employment protection and insolvency procedures within the Acquired Rights Directive, ${ }^{7}$ which contains provisions requiring the transfer of employment contracts to the buyer of a business or a part thereof upon its transfer, ${ }^{8}$ including those transfers which occur as a result of corporate rescue procedures. As the ARD provisions took the form of an EU directive, the form and method of implementation of the ARD was left to the member states as long as the intended results of the directive were achieved within national legislation. A number of derogations were also available within the ARD, including the potential to disapply the transfer provisions if the transferor were:

“...subject to bankruptcy proceedings or any analogous insolvency proceedings which have been instituted with a view to [the] liquidation...." of a company. ${ }^{9}$

3 The application of employee transfer provisions in corporate rescue procedures has not failed to cause controversy over the 37 years since its initial implementation, significantly as the derogation for insolvency procedures was not present in the original ARD. ${ }^{10}$ Many EU and national cases have caused further complications, particularly in relation to how national social policies affect the aims of corporate rescue with regard to the relative favouritism of the safeguarding of employment.

4 Social policy legislation also has an effect on how insolvency systems function in practice as the procedural outcomes can affect a variety of more vulnerable entities such as employees, their families, and the community at large. The relative protection of these more vulnerable entities differs from member state to member state according to diverse national views on the importance of social policy matters. A conception of the effectiveness of insolvency and business rescue procedures that includes a reflection upon the interaction of state and EU requirements of employee protection legislation would likely encourage a more holistic approach to improving cross-border insolvency within the EU. While such a matter is not strictly the prevue of EU insolvency law in its current scope, there are practical matters affecting how a pan-European rescue culture can function with the greatest efficiency when the conflicting goals of insolvency and the protection of employment are not recognised and, to some extent, managed.

\footnotetext{
${ }^{7}$ Council Directive 2001/23/EC of 12 March 2001 on the approximation of the laws of the member states relating to the safeguarding of employees' rights in the event of transfers of undertakings, businesses or parts of undertakings or businesses (OJ 2001 L82/16) (hereafter all Acquired Rights Directives will be referred to as the "ARD").

${ }^{8}$ Ibid., Article 3(1) (in Chapter II "Safeguarding of Employee's Rights").

${ }^{9}$ Ibid., Article 5.

${ }^{10}$ Council Directive 77/187/EEC of 14 February 1977 on the approximation of the laws of the member states relating to the safeguarding of employees' rights in the event of transfers of undertakings, businesses or parts of businesses (OJ 1977 L061/26).
} 
5 Among the EU member states that continue to exhibit fundamentally different approaches to corporate rescue and employment protection, the United Kingdom ${ }^{11}$ and France present two extreme examples. Through the comparison of two divergent but also highly influential EU jurisdictions, both historically and in the current political climate, an example of the obstacles facing overall convergence in this area can be demonstrated. The differences in these two jurisdictions will also help to highlight the problems associated with differing levels of social protection in terms of jurisdictional competitiveness and cross-border cooperation. This article will discuss the parallel evolution of corporate rescue and the implementation of the $\mathrm{ARD}$ in the UK and France with a view to illuminating these obstacles to convergence. While harmonisation in the area of social policy continues to be resisted by many member states, it could be that such harmonisation or at least convergence might assist in capturing a greater cohesiveness in cross-border business and insolvency and level the field of competition between the member states of the EU.

\section{The Evolution of Modern Insolvency Systems and Corporate Rescue}

\section{European Insolvency Systems}

6 The concept of bankruptcy has existed since ancient Roman magistrates were "breaking the benches" of traders who failed to repay their debts, and even before that among other advanced ancient races. The aims of ancient bankruptcy laws were initially the punishment, sometimes with extreme violence and barbarity, of those who had fallen into debt, regardless of reason or fault. The treatment of the early insolvent trader was by way of criminal sanction, resulting in a stigma that has been transmitted into modern concepts of insolvency by varying degrees in different jurisdictions. Decriminalisation of insolvency appears to have occurred in parallel with the growing importance of commercial life and the recognition that insolvency was sometimes an inevitable result of entrepreneurial ambition. ${ }^{12}$

7 In the UK, the origins of corporate insolvency law were linked to the development of the joint stock company during the nineteenth century. ${ }^{13}$ Until the 1860s, English bankruptcy law had the sole purpose of debt collection by seizing the debtor's assets. Early procedures functioned as a continuation of private remedies with some collective aspects. ${ }^{14}$ The Joint Stock Companies Winding-Up Act $1844,{ }^{15}$ the Bankruptcy Acts ${ }^{16}$ and the Companies Act of $1862^{17}$ introduced

\footnotetext{
${ }^{11}$ Hereafter referred to as the "UK".

${ }^{12}$ Omar, above note 2 , at 3-4, 10 .

${ }^{13}$ See the Joint Stock Companies Act 1844 (7 \& 8 Vict. c.110)

${ }^{14}$ See J. Sgard, "On Market Discipline: Bankruptcy, Debt Discharge and Renegotiation in England and France (17th - 19th Century)", Paper given at ISNIE Annual Conference, Reykjavik (2007), at 6-7.

157 \& 8 Vict. c. 111
} 
modern concepts of insolvency, such as the statutory regime for preferential debts, the pari passu ${ }^{18}$ principle and specific court led procedures for winding up. ${ }^{19} \mathrm{~A}$ number of Acts were passed and cases heard by the Chancery Court that helped to develop the law of insolvency further. However, this resulted in layers of law that were difficult to operate and prone to manipulation. These problems would attract the attention of reformers in the 1970s. ${ }^{20}$

8 French bankruptcy provisions were heavily influenced by the importation of the Italian legacy of lex mercatoria, ${ }^{21}$ which had fashioned bankruptcy into an open ended flexible instrument to resolve the debtor's estate. Early institutions of French bankruptcy law set out in Title XI of the Ordonnance sur le Commerce of 1673 under the reign of Louis XIV provided for amnesties and letters of royal pardon to compensate for the punitive nature of insolvency, as well as methods of liquidating a debtor's estate. ${ }^{22}$ The 1673 ordinance codified the customs and rules of the lex mercatoria, ${ }^{23}$ brought in by the flood of Italian traders and bankers during France's time of significant financial and commercial potency in the seventeenth century. ${ }^{24}$ Following the French Revolution of 1789 and the years of instability which followed it, Napoleon Bonaparte ${ }^{25}$ was able to take advantage of the chaos as a justification to impose order through the development of his Civil Code, which by 1808 included provisions on insolvency. The 1808 insolvency code offered a menu of options to the parties. However, the nature of the legislation retained its former repressiveness, giving courts wide powers of arrest and detention of insolvent debtors. While subsequent reforms codified some of the harsher provisions in 1838 and 1889 , the modern version of French insolvency law would not be recognisable until reforms taking place in the $1960 \mathrm{~s}^{26}$

9 Both the British and French jurisdictions approached insolvency in different ways in the seventeenth to nineteenth centuries. Britain focussed on liquidation as the sole result of engaging in the insolvency procedures, implying that the failure to

16 See Bankruptcy Act 1861 (24 \& 25 Vict. c.47); Bankruptcy Act 1869 (32 \&33 Vict c.71); Bankruptcy Act 1883 (46 \& 47 Vict. c.52); and Bankruptcy Act 1914 (4 \& 5 Geo. 5 c.59).

1725 \& 26 Vict. c. 134

18 Originally defined by Henry VIII in the Statute of Bankrupts 1542 (34 \& 35 Hen. VIII, c.4) as "a portion, rate and rate alike, according to the quantity of their debts."

19 See R. Goode, Sir, Principles of Corporate Insolvency Law (Student Edition) (2005, Sweet and Maxwell, London), at 6-9.

${ }^{20}$ See V. Finch, Corporate Insolvency Law: Perspectives and Principles ( $2^{\text {nd }}$ ed) (2009, Cambridge University Press, Cambridge), at 12-13.

${ }^{21}$ Sgard, above note 14.

22 See A. Sorensen and P. Omar, Corporate Rescue Procedures in France (1996, Kluwer Law International, London), at 22-23.

23 The "law merchant".

${ }^{24}$ See J. Sgard, "Bankruptcy, Fresh Start, and Debt Renegotiation in England and France (17th to 19th Century)", Chapter 14 in T. Safley (ed), The History of Bankruptcy: Economic, Social and Cultural Implications in Early Modern Europe (2013, Routledge, Abingdon Oxon) (223-235), at 224-225.

${ }^{25}$ Ruled from 1804-1814 and for 100 days in 1815.

${ }^{26}$ Sorensen and Omar, above note 22 , at 23 . 
pay one's debts needed to be sanctioned in the harshest manner possible. The British regime essentially expected debtors to deal with pre-crisis issues in order to avoid the draconian measures that would be taken should they no longer be able to repay their debts. France, however, had made renegotiation a possibility which softened the risk associated with business activities, allowing the creation of institutions that would help debtors to address financial shocks after they had occurred. ${ }^{27}$ Thus in France a concept of rehabilitation has roots which run much further into the past than does the UK.

\section{The Development of Corporate Rescue}

10 It has only been relatively recently that the concept of corporate rescue has been recognised as a legitimate aim of insolvency systems when views on insolvency changed in the 1960s. It had been realised that the economic benefits of the preservation of a company was an equally important consideration to the maximisation of creditor returns. ${ }^{28}$ The corporate rescue ethos initially developed in United States legal system. This concept was rapidly transplanted throughout the rest of the Western world. Its purpose was the revival of companies that are on the brink of economic collapse and salvaging those units that could be viably saved in order to promote the restoration of production, the safeguarding of employment, and the continued reward of capital and profit to the benefit of the economy at large. ${ }^{29}$ Thus, there was a development of preservation measures and external controls which were aimed at trying to prevent an irreversible decline in a company. This was the introduction of what would later be termed a "rescue culture" which encapsulated a new desire for economic entities to be able to impose greater controls on their futures. ${ }^{30}$ The rescue culture would eventually be integrated into the philosophy of the EU and become a part of the aims and purposes EU insolvency conventions and regulations.

11 In France, while the procedure of règlement judiciare ${ }^{31}$ was introduced in the first substantial reform of insolvency law in $1955,{ }^{32}$ the modern concept of corporate rescue in France arrived with the Law of $1967,{ }^{33}$ which provided for either a règlement judiciare or a liquidation judiciare. ${ }^{34}$ The former was chosen if the result of the process was likely to be a composition agreement with creditors while the debtor continued to trade, "rescuing" the business from liquidation. The latter was chosen if there was little likelihood of survival and resulted in the

\footnotetext{
${ }^{27}$ Sgard, above note 14 , at 7.

${ }^{28}$ Omar, above note 2, at 11-12.

${ }^{29}$ See P. Omar, "Thoughts on the Purpose of Corporate Rescue" (1997) 12(4) Journal of International Banking Law 127.

${ }^{30}$ Omar, above note 2, at 11-12.

31 Translated as "judicial settlement".

${ }^{32}$ Law no. 55-583 of 20 May 1955.

${ }^{33}$ Law no. 67-563 of 13 July 1967.

34 Translated as "judicial liquidation".
} 
liquidation of the debtors assets. The Court would choose from these options based on their view of the viability of the business. The law of redressement ${ }^{35}$ was introduced later in 1967 which was aimed at those businesses whose insolvency had grave consequences on the economy and were, while insolvent, not irretrievable. It included a moratorium and a mechanism for the settlement of debts and repayment. The reforms of 1967 were, however, designed to meet the requirements of a relatively prosperous France. The general outcomes were poor, saving few businesses from collapse and resulting in detriment to creditors, employees and shareholders alike. While many attempts at reform were made between 1967 and 1985, a new law on insolvency was only created during the latter year and would endure for almost a decade. ${ }^{36}$

12 The UK arrived a bit later in its adoption of the rescue culture. At the time when France was focussing on rescue and rehabilitation, the focus of UK insolvency legislation remained to a certain degree maximising returns to creditors by replacing the chaotic pursuit of individual claims with a statutory regime suspending creditors' rights and providing a mechanism for the orderly collection and realisation of assets and their distribution to creditors through a scheme of distribution. ${ }^{37}$ However, changes in the market, social policy, and the economic climate eroded this paradigm of British insolvency law, ${ }^{38}$ resulting in the initiation of massive reforms to its insolvency laws, enacted in 1986 and subsequently. ${ }^{39}$

13 The prospective entry of the UK into the European Economic Community ${ }^{40}$ in the 1970s also demanded that the UK should be capable of negotiating with other member states under a coordinated insolvency convention. The EEC had been contemplating the need for a coordinating bankruptcy convention in order to achieve harmonisation since a working party was convened in 1963 to examine the case for it. ${ }^{41}$ A report produced in 1970 included just such a convention drafted by the French for enactment in the member states. The purpose of the EEC Bankruptcy Convention was to universalise and unify the law, procedure and operation of bankruptcy throughout the existing member states. ${ }^{42}$ However, the philosophies and structures of national bankruptcy laws varied significantly throughout the member states in views of the role and weight attributed to creditor versus debtor interests, the survival of viable economic entities versus optimal creditor protection, and the

\footnotetext{
35 Often translates as "recovery".

${ }^{36}$ Sorensen and Omar, above note 22, at 24

${ }^{37}$ Goode, above note 19 , at 5 .

${ }^{38}$ See J. Silkenat and C. Schmerler, The Law of International Insolvencies and Debt Restructurings (2006, Oceana Publications, Dobbs Ferry NY), at 387.

${ }^{39}$ See M. Hunter, "The Nature and Functions of the Rescue Culture" (1999) Journal of Business Law 426 , at 455 .

${ }^{40}$ The precursor of the EU, which lasted from 1957 to 1973, hereafter referred to as the "EEC".

${ }^{41}$ Omar, above note 2, at 53-57.

${ }^{42}$ Hunter, above note 39 .
} 
protection of labour over economic efficiency. ${ }^{43}$ As a result of these seemingly irreconcilable differences, this draft was the first of a number of versions, including a draft produced in 1973 necessitated by the accession of three new member states, among them the UK. ${ }^{44}$

14 The UK assigned the 1973 draft EEC Bankruptcy Convention to a committee chaired by Sir Kenneth Cork to assess the acceptability of the draft convention in the context of the current British insolvency regime. The report published in 1976 highlighted a number of serious problems and anomalies in the British insolvency system that would need to be resolved if UK procedures were to be capable of harmonisation. ${ }^{45}$ While the Convention was viewed as being advantageous in terms of its perceived benefit to creditors, there would be many practical obstacles to overcome, including the vagueness of terms defining the centre of administration, an issue that remains under examination today. ${ }^{46}$ The process of assessing the Convention in relation to the UK insolvency regime did have the effect of focussing the attention of lawmakers on the need for reform, which resulted in the Insolvency Act of 1976. Its provisions were useful, but not fundamental in terms of reforming the UK system. ${ }^{47}$

15 The recognition that the previous reforms had not served to produce the fundamental changes required to reform the UK insolvency led to the appointment by the Secretary of State for Trade of the Insolvency Law Review Committee, also chaired by Sir Kenneth Cork, in 1977 (the "Cork Committee"). The Cork Committee was tasked with reviewing the law relating to insolvency, consider required reforms, examine the potential for formulating a comprehensive insolvency system, suggest possible less formal procedures and make any other relevant recommendations. A report of the Cork Committee (the "Cork Report") was then published in 1982 containing detailed and critical examination of all the existing procedures as well as a number of recommendations aimed at procedures that catered for rescue and rehabilitation of companies in distress. ${ }^{48}$ It stressed that a comprehensive review of insolvency was required not only for the purposes of negotiating with other member states, but also due to the poor state of the law, ${ }^{49}$ which:

“...has been tinkered with, patched and extended by false analogies so that today it is replete with anomalies, inconsistencies and deficiencies."

\footnotetext{
${ }^{43}$ See M. Balz, "The European Union Convention on Insolvency Proceedings" (1996) 70 American Bankruptcy Law Journal 485.

${ }^{44}$ Omar, above note 2, at 53-57.

${ }^{45}$ Hunter, above note 39.

${ }^{46}$ Omar, above note 2 , at 56.

${ }^{47}$ Hunter, above note 39.

${ }^{48}$ Idem.

${ }^{49}$ Finch, above note 20 , at 13-14.
} 
16 Further, the law was viewed as no longer fulfilling its obligation to the demands of fairness and justice in a modern society. ${ }^{50}$

\section{Business Rescue in the 1980s}

17 The EEC Bankruptcy Convention drafted in 1973 met with a number of obstacles that stood in the way of its willing adoption among the member states. There was significant conflict associated with the application of the concepts of universality and unity within the convention due to the widely different approaches to reorganisation and insolvency. Universality would guarantee that bankruptcies would be mutually recognised in member states while unity meant that a bankruptcy proceeding opened in one state would prohibit other states from opening proceedings. ${ }^{51}$ However, fundamental differences in the social and political stances among the member states as well as differing levels of legislative interventionism made the acquiescence to the interference with individual state sovereignty difficult to accept. Despite the continued difficulty in coordinating an EU wide insolvency convention, a second draft EC convention on insolvency was published in the official journal of the European Community ${ }^{52}$ in 1982 . Though comparable to the first draft that had received much criticism in 1973, the provisions were simplified and therefore welcomed as a potential working convention. A number of revisions, modifications and refinements were made but work on a new convention was halted due to a number of organisational issues within the EC. There was also a failure to reach a consensus on the second draft of the convention, so by 1984 it had become obvious that the convention in its current form was unrealistic. ${ }^{53}$ A European insolvency convention was now on a hiatus.

18 Both England and France saw changes to their insolvency systems in the mid1980s that shifted the focus from liquidation and creditor wealth maximisation to the rescue or rehabilitation of companies. A more social approach to insolvency had developed among Western nations which left scope for, and indeed justified, rescue activities according to the individual values contained within the corporate rescue principles of each jurisdiction. ${ }^{54}$

19 In the UK, one result of the Cork Report was a new definition of the aims of a good modern insolvency system, which should aim to:

"...recognise that the effects of insolvency are not limited to the private interests of the insolvent and his creditors, but that other groups in society

\footnotetext{
${ }^{50}$ See K. Cork, Sir (Chairman), Insolvency Law and Practice: Report of the Review Committee (1982) (Cmnd. 8558), at 10 (paragraph 9).

${ }^{51}$ Balz, above note 43 .

${ }^{52}$ Hereafter referred to as the "EC".

${ }^{53}$ Omar, above note 2, at 73 ; Balz, above note 43 .

${ }^{54}$ Finch, above note 20, at 245-246.
} 
are vitally affected by the insolvency and its outcome, and to ensure that these public interests are recognised and safeguarded." 55

20 This was an entirely new approach and perception of the aims of insolvency law, including a truly social message that was recommended to be incorporated in the imminent reforms. The Cork Report also recognised and formulated the concept of a rescue culture, stating that given that the failure of commercial enterprises has wide repercussions on a variety of stakeholders including but not limited to creditors, shareholders, employees, suppliers and others who would be adversely affected by business failure, a legitimate aim of insolvency laws should be to have concern for the livelihood and well-being of those dependent upon an enterprise. ${ }^{56}$ In the view of Cork Committee, the rescue culture would come to manifest itself in policies directed at the more benevolent treatment of insolvent legal entities as well as the more draconian treatment of the unscrupulous abusers of the system. It would also mean the steady removal of the stigmatising effect of bankruptcy. ${ }^{57}$ Though beneficent in their view of what the future should hold for insolvency, the Cork Committee's more socially oriented recommendations would mostly fall upon deaf ears.

21 The publication and consideration of the Cork Report by parliamentary legislators resulted in the passage of a new Insolvency Act in $1986,{ }^{58}$ preceded briefly by the Insolvency Act $1985 .^{59}$ The 1986 Act put into practice many of the suggestions published in the Cork Report. Cork's philosophy was, among other things, in favour of increasing the emphasis on rehabilitation of the company, as such, he recommended an administration procedure aimed at business rescue which would also ameliorate the plight of the unsecured creditor, who generally received nothing in traditional the old procedures. The procedure of administration was introduced as a court based procedure designed specifically for corporate rescue rather than asset realisation, focussed on the interests of unsecured creditors. While Cork's broad policy was aimed at the rehabilitation of the company, the 1986 Act did not go as far as he perceived was necessary to achieve this end. ${ }^{60}$

22 In France, the law was reformed in response to the changing economic climate. An emphasis on social policy encouraged a move to the maintenance of businesses in the place of liquidation. The harmful effects of unemployment caused by business failures in recessionary times were an influence on the creation of a corporate rescue policy biased toward the protection of employment and the rehabilitation of the business. ${ }^{61}$ The Law of $1985^{62}$ was passed with the objective of

\footnotetext{
55 Cork Report, at paragraph 198(i) (in Chapter 4).

56 Ibid., at paragraphs 203-204.

${ }^{57}$ Hunter, above note 39.

581986 c. 45.

591985 c. 65

${ }^{60}$ Finch, above note 20, at 15-21, 754-779.

${ }^{61}$ Sorensen and Omar, above note 22 , at 26.
} 
protecting employment at the risk of sacrificing creditors' rights. It envisaged three possible outcomes:

(1) a plan for continuing the business;

(2) a plan for its sale; or

(3) winding up with court supervision. ${ }^{63}$

23 The law reduced creditors' rights in favour of focusing on saving the business and the jobs associated with it at all costs. ${ }^{64}$ This approach was later viewed as too biased in favour of labour and unsuited to allowing the French economy to evolve in the highly competitive global market. ${ }^{65}$ However, the focus on employment protection and business rescue has not been lost in subsequent reforms to the French insolvency code.

24 Work was recommenced on an EC insolvency convention with the publication of proposals by a working group and then the draft of a European Bankruptcy (or Insolvency) Convention in 1991. The objectives of the new draft convention aimed to maintain a minimum level of opt-out, adopt a system of secondary proceedings, encourage the harmonisation of rules on conflict of laws, ${ }^{66}$ with appropriate account taken of the rescue regimes already present throughout the EC. ${ }^{67} \mathrm{~A}$ draft was produced in 1994 that was approved by the Council of Ministers in 1995. The draft met with substantial agreement and was welcomed as finally providing a realistic framework that could deal with the growing phenomena of cross-border insolvencies. Unfortunately, the convention never entered into force due to the obstinacy of the British, owing to disagreements over a crisis in the agricultural sector at the time. ${ }^{68}$

25 France underwent another set of reforms to its insolvency system in 1994. The purpose of this reform was the reinforcement of those measures available during the pre-insolvency stage, to redress some of the rights of creditors during insolvency proceedings, and to ensure greater equity in the plans resulting in the sale of a business. The 1994 reforms attempted to create more balance between the interests

\footnotetext{
${ }^{62}$ Law no. 85-98 of 25 January 1985.

63 See P. Théry, "The Evolution of Insolvency Law in France", Chapter 1 in W-G. Ringe et al., (eds), Current Issues in European Financial and Insolvency Law: Perspectives from France and the UK (2009, Hart Publishing, Portland OR) (1-16).

${ }^{64}$ Silkenat and Schmerler, above note 38 , at 143.

${ }^{65}$ Ibid., at 143 .

${ }^{66}$ Conflict of laws is otherwise known as private international law. It concerns relations across different legal jurisdictions between persons, and sometimes also companies, corporations and other legal entities.

${ }^{67}$ Balz, above note 43

${ }^{68}$ See P. Omar, "The European Insolvency Regulation 2000: A Paradigm of International Insolvency Cooperation” (2003) 15(1) Bond Law Review 215.
} 
of the company and its creditors. ${ }^{69}$ The UK system would not undergo another significant change until 2002 and France would follow soon thereafter.

\section{Business Rescue Today}

26 Following the failure of the 1995 European Bankruptcy (or Insolvency) Convention, the project was undertaken anew in the form of a proposal for what is now the EIR, which incorporated most of the 1995 Convention provisions verbatim. The use of an EU regulation as the legislative instrument meant that it would have direct effect in member states and would also confer power upon the Court of Justice to interpret it. The important elements of the EIR include the introduction of a principle of qualified unity in the rules for international jurisdiction in main proceedings based on the centre of main interests ("COMI"). Qualified unity precludes the opening of insolvency proceedings in other member states. The EIR also relies upon a principle of qualified universality in which main proceedings cover the whole of a debtor's worldwide assets, while allowing secondary proceedings in another member state with a number of restrictions. Mutual recognition of judgments on procedures heard in other EU jurisdictions is also conferred by the EIR. ${ }^{70}$

27 The EIR entered into force in 2002 with the purpose of enabling cross-border insolvency to operate efficiently and effectively, to provide for the coordination of the measures taken with regard to a debtor's assets and to avoid forum shopping. It was recognised within the EIR that it would not be practical to introduce insolvency proceedings with universal scope within the EU. ${ }^{71}$ The reasons for this lie with differing laws on security interests and the different preferential rights enjoyed by certain creditors during insolvency proceedings, ${ }^{72}$ in particular those of employees. By as early as 2006, issues associated with ambiguity in the definition of COMI were recognised in the EIR, as courts of different jurisdictions habitually interpreted this concept in different ways. ${ }^{73}$ This as well as other issues have led to recommendations to reform the EIR, culminating in proposals put forward by the European Commission in 2012 which have been debated and are currently under consideration by the European Council which will then seek to agree with the European Parliament upon proposed legislation. A new regulation is probably unlikely until $2016 .^{74}$

\footnotetext{
${ }^{69}$ Sorensen and Omar, above note 22, at 28.

${ }^{70}$ Goode, above note 19 , at 565-566.

${ }^{71}$ Recital 11, EIR.

72 See B. Wessels, "Cross-border Insolvency Law in Europe: Present Status and Future Prospects" (2008) 11(1) Potchefstroom Electronic Law Journal 68.

73 See G. Moss and C. Paulus, "The European Insolvency Regulation - The Case for Urgent Reform" (2006) 19(1) Insolvency Intelligence 1.

${ }^{74}$ See C. Laughton, "The European Insolvency Regulation: Amendment Proposals from the European Commission and the European Parliament - What next?” (2014 Spring) Eurofenix 20.
} 
28 The French system has undergone some species of reform nearly every decade since 1967. Its fundamental perspective on insolvency is as a collective procedure designed to distribute loss among all stakeholders in a company, subject to a certain hierarchy of distribution where employees are often privileged over creditors. The system exhibits redistribution tendencies that are recognisable as characteristics endemic to its version of social democracy. The balance between the rights of employees and creditors has been a consideration in attempts to reform the insolvency code ${ }^{75}$ leading to the Law of $2005 .^{76}$ In the period leading up to the promulgation of this law, it was observed that the previous insolvency code had in many instances failed to keep a company from falling into a terminal financial condition. Other pressures for reform included the coming into force of the EIR and a view that the French insolvency regime was too debtor friendly, particularly when this view is coupled with the perennial French concern for job security. ${ }^{77}$

29 The Law of 2005 includes an entirely new procedure (sauvegarde) ${ }^{78}$ which is available to debtor companies before the formal cessation de paiements ${ }^{79}$ situation occurs. It was designed as an anticipatory debtor-in-possession rescue procedure where the business could benefit from a moratorium while conceiving of and proposing a plan to creditors with a view to restructuring the business. ${ }^{80}$ This Law was reformed by ordinance in $2008,{ }^{81}$ partly as a result of the poor utilisation of the sauvegarde procedure. In large part the 2008 ordinance addresses perceived inefficiencies in this procedure with the aim of encouraging recourse to upstream rescue by clarifying the criterion for access to the procedure, the functioning of creditors' committees and their role in the procedure. It also aims at enhancing the operation other insolvency procedures such as conciliation and judicial liquidation. ${ }^{82}$ A further decree in March 2014 made additional modifications to the sauvegarde procedure aimed at facilitating the anticipation of the worsening of financial difficulties, enhancing process efficiency in relation to the roles of creditors, debtor and shareholders, and to more realistically treat those situations that are irrecoverable in relation to the rights of creditors and debtors. It also aims to improve the procedural rules in relation to security, simplicity and efficacy. ${ }^{83}$

\footnotetext{
${ }^{75}$ Omar, above note 2, at 129.

${ }^{76}$ Law no. 2005-845 of 26 July 2005.

77 See C. Dupoux and D. Marks, "French Bankruptcy Law: Putting the Safeguards in Place" (2006) 3(4) International Corporate Rescue 207.

${ }^{78}$ Translated as "preservation".

${ }^{79}$ Translated as "payment failure".

${ }^{80}$ See P. Omar, "Preservation and Pre-packs à la française: The Evolution of French Insolvency Law" (2011) 22(8) International Company and Commercial Law Review 258.

${ }^{81}$ Law no. 2008-676 of 4 August 2008 on the Modernisation of the Economy.

82 Omar, above note 80.

83 "Rapport au Président de la République rélatif à l'ordonnance no. 2014-326 du 12 mars 2014 portant réforme de la prévention des difficultés des entreprises et des procédures collectives", published in the Journal Officiel.
} 
30 While the most recent reforms have softened the draconian treatment of creditors relative to employees, apart from heavier consultation obligations issued from the most recent decree, the social objectives of protecting employment continue to affect the way in which courts deal with specific insolvency cases. In general, there is an emphasis on trying to save jobs in the French system. At times there are compromises made between the social objectives and financial objectives in cases of businesses sold as going concerns. ${ }^{84}$ This can result in choices that favour employees but result in reduced funds available in distributions to creditors. In other words, the social objectives of employment protection and their costs reduce the value of a business being sold; thereby reducing the distributions available to creditors, but this is generally acceptable due to the French emphasis on workers' rights.

31 Insolvency law in the UK today is still based on the Insolvency Act 1986; however, changes were made to it through the Enterprise Act 2002. ${ }^{85}$ The EA effected a significant change in the stance on insolvency and corporate rescue in the UK. The view was now that preventative intervention should take place at the earliest opportunity, thus the EA introduced a number of reforms that were designed to assist troubled companies by fostering the rescue culture. ${ }^{86}$ What is meant by this in British terms is that insolvency legislation should take on a positive and protective role rather than a corrective and punitive role. Interpretation of socio-economic related statutes should be deliberately inclined towards giving a positive and socially profitable meaning, rather than a negative and socially destructive one. ${ }^{87}$ The EA was aimed at the furtherance of the rescue culture and also encouraged companies to consider insolvency risks in advance of a final financial crisis. ${ }^{88}$

32 The EA replaced administrative receivership with the provisions of the administration procedure and ring-fenced a portion of funds for the benefit of unsecured creditors. ${ }^{89}$ The administration procedure was also streamlined to make it easier and less expensive to use and also to give unsecured creditors more rights. One of its original purposes was to provide a means of rehabilitating a debtor company in financial crisis and protecting it from creditor claims. This was reinforced in the $\mathrm{EA}^{90}$ by the inclusion of Schedule B1 in the Insolvency Act which provided for three hierarchical objectives of administration:

(1) to rescue the company as a going concern;

\footnotetext{
${ }^{84}$ See R. Stevens, "Comments and Discussion Report", Chapter 13 in W-G. Ringe et al., above note 63 (207-210).

${ }^{85} 2002$ c. 40 (hereafter referred to as the "EA").

${ }^{86}$ Finch, above note 20, at 254 .

${ }^{87}$ Hunter, above note 39.

${ }^{88}$ Finch, above note 20, at 255 .

${ }^{89}$ See V. Finch, "Corporate Rescue in a World of Debt" (2008) 8 Journal of Business Law 756.

${ }^{90}$ Silkenat and Schmerler, above note 38, at 388 .
} 
(2) to achieve a better result for creditors in a winding up; or

(3) if the first two are not reasonably practicable, to realise property for the benefit of secured or preferential creditors. ${ }^{91}$

33 While the existence of rehabilitative procedures and their priority in usage is uncontested, some insolvency practitioners have informally expressed their disillusionment with them in practice. In the experience of one anonymous practitioner, what actually happens in the prioritising of outcomes in administration procedures is not necessarily what one would expect from the letter of the law or the findings in cases.

\section{Employees in Business Rescue Procedures}

34 One area where France and the UK share a small commonality is the position of employees as preferential creditors, though the level of preference diverges. In France, unpaid employees are creditors in an insolvency procedure but have certain additional benefits. Employees enjoy a general lien over the employer's property which stands as a guarantee for six months' worth of wages and compensation in place of wages, though the lien does not enjoy a high rank in the order of priority. Employees also have access to a guarantee fund where funds are not readily available to pay employee claims. ${ }^{92}$ Employees are also given a super priority for a limited part of their claim which ranks above all other claims, including those of secured creditors and also affords employees the facility to avoid the disruption and delay of the proceedings so that they can be paid quickly. In the event that redundancies are envisaged, an employee safeguard plan must be put in place which serves to ensure that everything has been done to prevent the loss of jobs, further indicating the favouritism enjoyed by employees in these situations in France. Though governed by the EU Directive on Collective Redundancies, ${ }^{93}$ France has given far greater protections than the minimum standards set out in the Directive. Most procedures that may have an effect on the rights of employees have significant court involvement as well. ${ }^{94}$

35 Employees in the UK also retain the status of preferential creditors. ${ }^{95}$ Unpaid wages and accrued holiday pay are given preferential priority in a distribution. These are payable in advance of unsecured claims out of the assets of the company. Employees are also able to claim against the state National Insurance Fund in respect of a number of unpaid debts associated with their employment. Unpaid

\footnotetext{
${ }^{91}$ Schedule B1, paragraph 3, Insolvency Act 1986 (1986 c. 45).

92 Fund available from the Association pour la Gestion du Régime d'Assurance des Créances des Salariés (the "AGS").

${ }^{93}$ Council Directive 98/59/EC of 20 July 1998 on the approximation of the laws of the member states relating to collective redundancies (OJ 1998 L255/16).

${ }^{94}$ See A. Tetley and M. Bayle, "Insolvency Law in France", in O. Lobo et al., (eds), World Insolvency

Systems: A Comparative Study (2009, Sweet and Maxwell, Toronto) (195-279).

${ }^{95}$ Silkenat and Schmerler, above note 38, at 397.
} 
employee pension contributions are also preferential for up to four months. Unpaid employer pension contributions are also preferential, but limited. ${ }^{96}$ In terms of collective redundancies, the UK took a lighter option from the Directive on Collective Redundancies in its implementation which has allowed a number of cases to circumvent the consultative requirements of the Directive. This has not occurred without a significant amount of litigation on certain ambiguous terms. In general, UK employees do not enjoy the level of protection afforded to their counterparts in France.

36 There is an inevitable tension between creditors' rights in insolvency and the rights of a company's employees. ${ }^{97}$ If the goal of insolvency is to maximise the distribution to creditors, then preferring employees raises their claims above those of other creditors and effectively take funds out of the pool of assets to satisfy their claims in preference, creating a super priority which raises issues of fairness to the treatment of other creditors in insolvency. ${ }^{98}$ There is also an argument that the concept of corporate rescue brings with it parallel goals of a social nature, such as the protection of employment, the effect of business failure on a community, and questions that go beyond the purely business oriented outcomes of insolvency. European Social Policy has succeeded in applying its views on the importance of employment protection through the application of the ARD on business transfers generally, but including those transfers occurring out of corporate rescue procedures. The latter has caused controversy related to the effect that its application may have on the success of business rescue and whether the goals of safeguarding employees can be reached if the liabilities associated with them then cause businesses to fail. However, other jurisdictions have accepted the application of the ARD in rescue procedures as a natural result of national social policy initiatives.

\section{EU Social Policy and Acquired Rights}

\section{The Background to a Social Europe}

37 Social policy refers to the provision of services, income and protection for those citizens unable to or who are in a weaker bargaining position to support or protect themselves. The basis for social policies stem from human rights protected by the EU and national court systems and the social ills they are aimed to resolve. Though the background to social policy is universal, the level and form of investment in these matters vary from country to country. ${ }^{99}$ Until fairly recently, social policy had

\footnotetext{
${ }^{96}$ Finch, above note 20, at 756-757.

${ }^{97}$ Goode, above note 19 , at 52 .

${ }^{98}$ Finch, above note 20, at 754-779.

99 See P. Kettunen and C. Wolff, "Europeanisation through the Back Door: EU Social Policy and the Member States" (2010) 47(5) Politička misao 144, at 146.
} 
been viewed as a poor relation in the process of European integration. The Treaty of Rome merely exhorted the member states to improve working conditions and standard of living for workers without actually conferring any rights on the workers themselves. The initial view was that economic integration itself would ensure an optimum social system through the removal of obstacles to free movement. The Spaak Report ${ }^{100}$ drawn up prior to the Treaty of Rome rejected the idea of trying to harmonize social policy within the EC because it was thought that as higher costs tended to accompany higher productivity, the differences between countries were not as great as they appeared. ${ }^{101}$ In the early days of the EC, the absence of a clearly identifiable social policy can be explained by the fact that social policy and labour law lay at the heart of the sovereignty of member states and were viewed as a means of preserving their integrity and political stability. ${ }^{102}$

38 EC social policy was evolving on a similar theme in the 1970s to that of corporate rescue. The social dimension of the EC had begun to grow in importance, recognising that a philosophy of economic growth based on neo-liberal ideology was not capable of addressing the social problems consequential to economic integration. An Action Programme ${ }^{103}$ was conceived with the intention of attaining full and better employment, improving working conditions, and increasing the involvement of management and labour in the economic and social decision making within the Community as well as in the life of the undertaking. ${ }^{104}$ Following on from this, an ambitious social action plan proposed mandates in the areas of health and safety, minimum wages, working hours, employee participation and contract labour. ${ }^{105}$ The resulting legislative activity culminated in the adoption of a number of directives in the fields of sexual equality, health and safety, the transfer of undertakings and insolvent employers. ${ }^{106}$ However, the Commission's successes in these areas were overshadowed by its failures; its proposals simply strayed too far from national practices in many member states. ${ }^{107}$

39 In the 1980s, the UK government objected to the interference with its sovereignty which EC social policy represented. During this period of increased social consciousness in the EC, the ruling UK Conservative party was in favour of labour market deregulation to ensure maximum labour market flexibility. While the

\footnotetext{
${ }^{100}$ Rapport des Chefs de Délégations, Comité Intergouvernemental (21 April 1956), at 19-20, 60-1.

101 See C. Brewster and P. Teague, European Community Social Policy and its Impact on the UK (1989, Institute of Personnel Management, London), at 52.

102 See W. Streeck, "Neo-Voluntarism: A New European Social Policy Regime?" (1995) 1 European Law Journal 31.

103 OJ 1974 L6/24.

${ }^{104}$ See C. Barnard, EC Employment Law ( $3^{\text {rd }}$ ed) (2006, Oxford University Press, New York NY), at 821.

${ }^{105}$ See J. Addison, "In the beginning, there was social policy: developments in social policy in the European Union from 1972 through 2008” (2009) The Rimini Centre For Economic Analysis PR 01-09 1.

${ }^{106}$ Barnard, above note 104 , at 9

107 Addison, above note 105 .
} 
European Commission recognised the need for a flexible workforce, it refused to compromise on its commitment to safeguard the rights of employees. The UK was able to impede the will of the Commission, however, as social policy measures required unanimity at that time. This was to change with the introduction of the Single European Act in 1989 when the UK conceded ground on the requirement for unanimity, accepting that qualified majority voting could be used in relation to health and safety and the gradual implementation of minimum standards. The concession of the UK gave the Commission a means of circumventing the UK veto despite British hostility toward EC social policy objectives. The EC could surreptitiously include more broadly employment related issues under the heading of health and safety which required only qualified majority voting. In this way, directives on working time, pregnant and young workers were passed, despite the fact that these also related to the rights and interests of employed persons which continued to required unanimous voting. ${ }^{108}$

40 In 1991, the Commission sought to extend the qualified majority voting further into the field of social policy. A new social chapter was introduced into what was to become known as the Maastricht Treaty. ${ }^{109}$ However, the UK's staunch objections to the social chapter required a political compromise in order to save the treaty as a whole. The social chapter was therefore left out of the main body of the Maastricht Treaty, placing it instead in a separate Social Policy Agreement and Social Policy Protocol, making it possible for the UK to opt out of its effects. ${ }^{110}$ The existence of this "two track social Europe" was short lived as the UK Labour party came to power in 1997 with the promise of social justice and inclusion. In addition to a number of labour reforms, the government also chose to accept the Social Chapter of the Maastricht Treaty and would take the necessary steps to bind itself thereto. ${ }^{111}$

41 The Treaty of Amsterdam incorporated the provisions of the Social Chapter directly in 1997. It also created a new employment chapter which set a high level of employment as a central objective of the EU. In 1999 employment policy moved to the forefront of the agenda in the EU, ${ }^{112}$ admitting through its inclusion that there were increased interdependencies between economic policy of the EU and national social policies. If national markets were closed and independent, social policy would remain a domestic concern. However, once the EU had created the Common Market with a common currency, social policy in one country becomes relevant to other states as it can affect the integrity of the currency and the competitiveness of the larger trans-national market. ${ }^{113}$

\footnotetext{
${ }^{108}$ Barnard, above note 104, at 11-12.

109 Treaty on European Union.

${ }^{110}$ See J. Fairhurst, Law of the European Union (2010, Pearson Education Limited, Harlow), at 15.

111 Ibid., at 16.

112 Addison, above note 105.

${ }^{113}$ See D. Trubek and L. Trubek, "Hard and Soft Law in the Construction of Social Europe: The Role of the Open Method of Coordination” (2005) 11(3) European Law Journal 343, at 345.
} 
42 The Treaty of Nice which came into effect in 2003 also provided for a fundamental development of social policy in the EU. In it the Charter of Fundamental Rights of the EU was adopted. In terms of its effects on legislation under the Social Chapter, it at least helps to provide a counterweight to the neoliberal orientation of the Treaty and provides the Court with the jurisdiction to reconcile social and economic rights, at least to the extent that the scope of EU law will allow. It was hoped that this would also avoid states removing social rights as a means of improving competitiveness within the market in what has been termed a "race to the bottom". ${ }^{114}$ However, EU social policy remains within the domain of member states to determine, requiring unanimous decision making in areas falling under its definition. ${ }^{115}$ While true that the EU Treaties have so far left the competence to regulate social policy to the member states, ${ }^{116}$ since the Lisbon strategy of 2000 there has been a push to modernise the European social model by investing in human resources and combating social exclusion. However, these exhortations were lost in the financial crisis and member state adherence to their sovereignty over social policy has thus far triumphed. ${ }^{117}$ Social institutions are also deeply embedded in each country's larger societal framework and history and therefore cannot be easily amalgamated. ${ }^{118}$

\section{The Acquired Rights Drama}

43 The encouragement of cross-border competition would inevitably lead to corporate restructurings and it was acknowledged that such competition could then mean a loss of job security for employees subject to changes accomplished through reorganisations which could include business transfers. Thus a need arose to protect employee job security in the event of business transfers. The acquired rights legislation was born partly out of a growing concern about the absence of a "social face" to the Common Market ${ }^{119}$ as well as the fact that the prevailing frameworks in both Germany and France had already provided acquired rights legislation that protected employees on the transfer of a business and were consequently in a potentially disadvantageous competitive position with the rest of the EU lacking similar legislation. ${ }^{120}$

\footnotetext{
${ }^{114}$ Barnard, above note 104, at 28-32.

${ }^{115}$ See N. Esentürk, "EU Social Policy: Progressive Development in Legal and Governance Aspects" (2010) UK Social Policy Association Paper, copy available at: <http://www.socialpolicy.org.uk/lincoln/Esenturk.pdf>, at 2-3 (last accessed 15 June 2014).

${ }^{116}$ See K-J. Bieback, "Harmonisation of Social Policy in the European Community" (1991) 32(4) Les Cahiers de Droit 913 , at 916.

${ }_{117}$ See G. Ross, "The Revenge of Neglected Issues: EU Founders and Social Policy" (2011) 29(2) French Politics, Culture and Society 90, at 95-100.

${ }^{118}$ Kettunen and Wolff, above note 99, at 148.

${ }_{119}$ Barnard, above note 104 , at 619 .

${ }^{120}$ See N. Adnett, "The Acquired Rights Directive and Compulsory Competitive Tendering in the UK: An Economic Perspective" (1998) 6(1) European Journal of Law and Economics 69, at 71.
} 
44 The premise of the ARD is that:

"it is necessary to provide for the protection of employees in the event of a change of
employer, in particular, to ensure that their rights are safeguarded." 121

45 It operates to transfer employment contracts to the buyer of a business undertaking or part of a business undertaking, ${ }^{122}$ effectively granting employees a property right in their job. ${ }^{123}$ Rights and obligations arising under the employment contracts transfer to the buyer. Both the buyer and the seller of the undertaking remain joint and severally liable in respect of those obligations arising prior to the transfer. Member states were given latitude in relation to any obligations to notify a buyer of the rights and obligations connected with the transferring contracts. The terms of collective agreements also transfer, though member states are given the option to limit the period for observing those terms and conditions. Pension rights are excepted from the operation of the Directive and will not transfer unless a Member state provides otherwise, as indeed France so provides. ${ }^{124}$

46 The transfer does not constitute grounds for dismissal. Any dismissal by reason of the transfer is prohibited and will attract liability under a member states employment laws. Dismissals can be made if there is an economic, technical or organisational reason entailing changes in the workforce. If a contract is subsequently transferred and as a result there are substantial and detrimental changes in the conditions of the working environment, an employee may choose to deem his contract as terminated and the employer will be deemed responsible for that termination. ${ }^{125}$ Rights also extend to preserving the terms and conditions of employment. The terms of a contract cannot be changed by reason of the transfer unless such changes are agreed with the employees or their representatives. ${ }^{126}$ If terms are changed without due consultation, an employee may choose to resign citing an employer breach of the employment contract. In UK law, such a termination by an employee will be regarded as being a constructive dismissal. ${ }^{127}$ There are also significant consultation and information requirements associated with business transfers which can incur significant liabilities for an employer if not properly done. $^{128}$

47 France has had acquired rights legislation protecting employment during business transfers in place since 1928. This law required that where there was a change in the juridical situation of an employer, such as the transfer of a business,

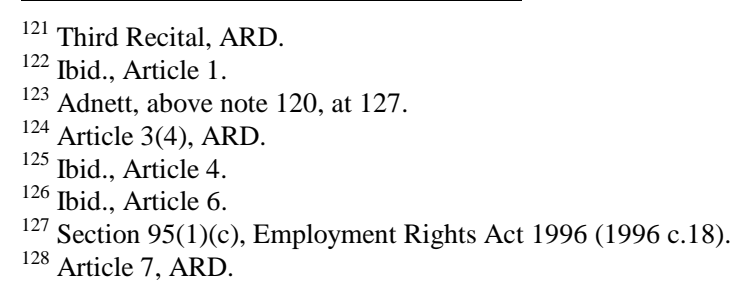


all employment contracts would continue between the new employer and employees of that enterprise. ${ }^{129}$ The failure of a business, except in cases of force majeure, would not free an employer from his obligation to respect the notice periods of its employees and provide an indemnity for any losses which may accrue. ${ }^{130}$ Today the position is the much the same, though the new employer is not liable for the obligations encumbering the old employer if the transfer is being made in relation to the sauvegarde procedure, redressement or judicial liquidation. ${ }^{131}$

48 In contrast, the first UK legislation conferring continuity of employment on a business transfer ${ }^{132}$ would apply only if the employees were voluntarily retained by the purchasing firm. There was no concept of automatic transfer as this would conflict with the fundamental freedom of contract. ${ }^{133}$ For this reason, it was not until the Labour party came to power in the UK in $1997,{ }^{134}$ under the promise of social justice and inclusion that the UK accepted the Social Chapter of the Maastricht Treaty, bringing the UK under the governance of EU social policy initiatives. ${ }^{135}$ As such, any directives passed under the Social Chapter would require implementation.

\section{Implementation of the Acquired Rights Directive}

49 Business transfers are a natural occurrence in the life of a business enterprise. The transfer of employees can benefit a purchaser through the experience and skill they bring to the enterprise. However, the position is not necessarily the same for the transfer conceived during insolvency procedures. The ARD now provides optional derogations in the case of insolvency procedures, but it has been unclear whether this would apply across the whole gamut of insolvency procedures or only in liquidation. Thus the acquired right drama begins, though not for all EU member states. For France, the concept of acquired rights was already a fundamental value enshrined within its legal system. In the UK, however, much case law has argued the point as to whether the implementing legislation, the Transfer of Undertakings (Protection of Employment) Regulations ${ }^{136} 1981$ and 2006, should apply in business transfers out of administration and many writers have argued that its application to such a situation will have adverse effects on the outcome of the procedure owing to the inevitable reduction in the intrinsic value of the business due to the cost of liability associated with the transferring employment contracts. Its

\footnotetext{
${ }^{129}$ Barnard, above note 104, at 620.

${ }^{130}$ Article L.122-12, Code du Travail (repealed by Ordonnance no. 2007-329 of 12 March 2007).

${ }^{131}$ Ibid., Articles L.1224-1 and 2 (in Chapître IV: Transfert du contrat de travail).

${ }^{132}$ Contracts of Employment Act 1963 (repealed).

133 See A. Baker and I. Smith, Smith \& Woods Employment Law (2010, Oxford University Press, New York NY), at 541.

134 The Labour Government was in power from 1997-2010.

${ }^{135}$ Barnard, above note 104, at 22.

${ }^{136}$ Hereafter referred to as "TUPE".
} 
effects could thus usurp both the aims of the rescue culture and the aims of the ARD in safeguarding employment.

\section{The Insolvency Exception}

50 The first ARD did not expressly exclude business transfers on insolvency from its scope, but following Abels ${ }^{137}$ the European Court of Justice said that it would not apply to transfers of undertakings which took place during the winding up of insolvent companies. ${ }^{138}$ Thus employee contracts would not transfer if a business was sold without the intention to continue trading. ${ }^{139}$ The effect was not so clear in relation to those insolvency procedures such as administration where one of the goals is to continue the business but an alternative outcome might be liquidation. Problems were recognised at an early stage in relation to the obligation to take over the liabilities associated with employment contracts in the context of rescue procedures as it was believed that this would act as a disincentive to the rescue of troubled businesses and would actually harm employees by not allowing their employer to be rescued from insolvency and protect at least some of the jobs. ${ }^{140}$

51 In Abels, the Court argued that the interests of employees would be better served if the ARD 1977 did not apply on an insolvent business transfer with a view to liquidation as it would likely result in a loss of job security and worker welfare, contrary to the purpose of the directive. Further, the ARD might dissuade a potential transferee from acquiring parts of a business of the company due to costs associated with employees, leading to liquidation and resulting in the loss of all jobs. Another reason for relaxing the rules was attributed to the special nature of insolvency laws, designed to weigh up the competing interests involved. It was accepted that insolvency rules could derogate at least in part from the social policy bias toward the position of employees, given the potential adverse results it may otherwise have. ${ }^{141}$

52 A distinction was drawn by the court in Abels between terminal and nonterminal insolvency proceedings. This was incorporated in the ARD $1998^{142}$ which was then consolidated under the current ARD. Article 5(1) states that unless provided otherwise by a member state, employee contracts will not transfer where the transferor is the subject of insolvency proceedings instituted with a view to the

\footnotetext{
137 Abels v Bedrijfsvereniging voor de Metaalindustrie en de Electrotechnische Industrie (Case 138/83) [1985] ECR 469.

${ }^{138}$ See S. Hardy, "Some TUPE Implications for Insolvency Lawyers" (2001) 4 Insolvency Law 147.

${ }^{139}$ See D. Pollard, Corporate Insolvency: Employment and Pension Rights $\left(4^{\text {th }}\right.$ ed) (2009, Bloomsbury Professional Limited, Haywards Heath), at 316.

${ }^{140}$ See M. Sargeant, "TUPE - The Final Round" (2006) Journal of Business Law 549, at 562.

${ }^{141}$ Barnard, above note 104 , at 647-648.

${ }^{142}$ Council Directive 98/50/EC of 29 June 1998 amending Directive 77/187/EEC on the approximation of the laws of the member states relating to the safeguarding of employees' rights in the event of transfers of undertakings, businesses or parts of businesses (OJ 1998 L201/88).
} 
liquidation $^{143}$ of the assets of the company under the supervision of a competent public authority. ${ }^{144}$ It was a choice available to each member state to apply this insolvency exception. The UK utilised this derogation but it did not fully solve the problem, rather, owing to a lack of specific definition within UK insolvency procedures, it complicated the matter. The series of European cases which clarify the position as to when the exclusion will apply is long and complex and have done little to clarify the position in the UK. ${ }^{145}$ The same controversy has never been present in the French system, which is no surprise given its influence on the enactment of the first ARD. The fact that such a fundamental difference in national policy exists demonstrates one level of difficulty associated with convergence in this area of the law.

\section{Corporate Rescue and Acquired Rights Conflict in the UK}

53 Given the history of Britain's stubborn opposition to European social policy, it is a wonder that the ARD 1977 had any effect in the UK at all. The introduction of the concept of acquired rights radically altered the treatment of employment contracts during business transfers. Due to acquired rights legislation, employees subject to a business transfer would enjoy the benefit of an automatic transfer of their employment contracts to the purchaser of the business to which the employees were attached. ${ }^{146}$ The legislation also signified a departure from the previously rigid common law doctrine of freedom of contract as it imposes continuity of employment rather than terminating the employment relationship upon the change of party identities. ${ }^{147}$

54 The initial implementation of the ARD brought little fanfare. It was expected that it would have little impact and would be of limited commercial importance, particularly for mergers and acquisitions as it did not apply to business transfers accomplished through share sales, while the ARD would only apply to business transfers occurring through asset sales leading to the sale of an economic entity, or a functioning business unit, which retains its identity following the transfer. It was envisaged that prior to the disposal of an insolvent undertaking, an insolvency practitioner would create a wholly owned subsidiary to which the business would be transferred to avoid the operation of the ARD. Employees would be retained by the transferor and then loaned out to the subsidiary, which operated with no employees under legal contract. The subsidiary business would then be disposed of

\footnotetext{
${ }^{143}$ Emphasis added by author.

144 Article 5(1), ARD.

${ }^{145} \mathrm{See}$, in addition to the previously mentioned Abels, D'Urso v Ercole Marelli Elettromeccanica General Case 362/89 [1991] ECR I-4105; Jules Déthier Equipement SA v Jules Dassy Case C-319/94 [1998] ECR I-1061; Eurpiéces SA (in liquidation) v Wilfried Sanders and Automotive Industries Holding Company SA Case C-399/96 [1998] ECR I-6965.

${ }^{146}$ See G. Pitt, Employment Law ( $7^{\text {th }}$ ed) (2007, Sweet and Maxwell, London), at 305-306.

147 See W. Derbyshire and S. Hardy, TUPE Law \& Practice $\left(2^{\text {nd }}\right.$ ed) (2009, Spiramus Press Limited, London), at 1-6.
} 
with no employment contracts to fetter the negotiations. This scheme of avoidance, termed "hiving down," was clearly in breach of the aims of the ARD as it circumvented the protection of employment as was intended by the ARD. This practice no longer avoids the operation acquired rights under the TUPE $2006^{148}$ following the judgment in Litster, ${ }^{149}$ which continues to apply despite amendments to the Regulations.

55 The Conservative Government of the 1980s found the interference of EU social policy with UK sovereignty distasteful. After an arduous legislative process which began with a resentful copy and paste method of legislation in TUPE $1981,{ }^{150}$ the UK has finally arrived at an implementation of the ARD which, at least to some extent, satisfies the minimum requirements for implementation in the TUPE 2006. Judicial development of the law has increased the impact of acquired rights, showing that a transferee could not simply dismiss transferring employees or insist on a change in terms and conditions. ${ }^{151}$ The cost of inherited employees has become a significant consideration in commercial negotiations now that the option of dismissing employees before the transfer ${ }^{152}$ and hiving down ${ }^{153}$ whereby the liability of employment contracts transfers could be avoided ${ }^{154}$ are no longer available. The absence of the commercially helpful procedures has made the question of the application of TUPE in corporate rescue procedures even more important to determine.

56 A number of cases in the UK have continued to examine the position of corporate rescue procedures under the insolvency exception. Oakland $v$ Wellswood $^{155}$ was the first in a series of cases that have extended the reach of acquired rights into the realm of corporate rescue. In Oakland, the Employment Appeal Tribunal found that administration proceedings, in particular pre-pack administrations instituted with a view to liquidating the company, would benefit from the insolvency exception in TUPE. ${ }^{156}$ Employees subject to a pre-pack administration would not automatically transfer to the buyer of the business package. The company was deemed as being in a form of terminal insolvency and therefore subject to relevant bankruptcy proceedings as required by the exception in TUPE. ${ }^{157}$ There followed $O T G,{ }^{158}$ a case which sought to clarify certain questions left out in Oakland. Disagreeing with the approach in Oakland, an

\footnotetext{
${ }^{148}$ Transfer of Undertakings (Protection of Employment) Regulations 2006 (SI 2006/246).

${ }^{149}$ Litster v Forth Dry Dock and Engineering Co Ltd [1989] ICR 341.

${ }^{150}$ Transfer of Undertakings (Protection of Employment) Regulations 1981 (SI 1981/1794).

${ }^{151}$ Baker and Smith, above note 133, at 542.

${ }^{152}$ Litster, above note 149, and cases mentioned, above note 147.

${ }^{153}$ Re Maxwell Fleet and Facilities Management Ltd (in administration) (No.2) [2001] 1 WLR 323

${ }^{154}$ Derbyshire and Hardy, above note 147, at 60-61.

155 Oakland $v$ Wellswood (Yorkshire) Ltd [2009] EWCA Civ 1094; [2010] BCC 263.

156 See A. Kastrinou, N. Shah and O. Gough, "Corporate Rescue in the UK and the Effect of the TUPE" (2011) 32(5) Company Lawyer 131, at 136.

${ }^{157}$ Pollard, above note 139.

${ }^{158}$ OTG Limited v Burke \& Others [2011] UKEAT 0320/09.
} 
absolute approach was taken which meant that the insolvency exception could never apply to administrations. It was viewed that the true purpose of administration would always default to the rescue of a company given the hierarchical nature of its description in Schedule B1 of the Insolvency Act 1986. As such, it could not be instituted with a view to liquidating the company. ${ }^{159}$

57 A more recent case, Key2 Law, ${ }^{160}$ argued on appeal that it was right to take a fact based approach, despite the seemingly prioritised terms of the administrator's obligations of:

(1) rescuing the company as a going concern, or

(2) achieving a better result for the company's creditors other than through liquidation, or

(3) realising property to make a distribution to secured or preferential creditors. ${ }^{161}$

58 It was viewed as unrealistic to regard rescuing a company as a going concern as reflecting the primary objective in administration. In practice, there are cases where there is no prospect for a rescue as the sole objective of an administration will result in the realisation of assets in the best interests of creditors. ${ }^{162}$ In this case the administration order had been made for the purpose of disposing of the undertaking to a third party for a consideration which would enable a distribution to creditors. It was argued that the administration order was therefore made with a view to liquidation and therefore fell within the intendment of the insolvency exception. ${ }^{163}$

59 The Court of Appeal disagreed, finding that in principle it was unsatisfactory to depend on evidence leading up to the making of an order as key in determining whether or not an administration procedure can be considered as having been taken with a view to liquidation. The fact based argument produces uncertainty as to the objective intended to be achieved by any administrative appointment, which is to firstly try to find a means of rescuing the undertaking. The Court also regarded it as wrong to identify the purpose of an administrative appointment by reference to the objectives of their pre appointment considerations, foreseeing what such an appointment may be reasonably likely to achieve. The determination must look to the purpose of the procedure triggered by the making of the order rather than the intention of the people involved in the making of it. To this end, the purpose of an administration is clearly set out in Schedule B1 of the Insolvency Act 1986 and its headline purpose is to try to rescue the business, only resorting to the liquidation of assets if that primary purpose proves impossible to achieve. ${ }^{164}$ In all cases, it is this

\footnotetext{
159 See P. Cranston, “Case Comment: Absolutism over Realism” (2011) 24(3) Insolvency Intelligence 47

${ }^{160}$ Key2Law (Surrey) LLP vs Gaynor De'Antiquis and Secretary of State for Business Innovation and Skills [2011] EWCA Civ 1567.

${ }^{161}$ Schedule B1, paragraph 3, Insolvency Act 1986.

${ }^{162}$ Key2Law, above note 160, at paragraph 88 .

${ }^{163}$ Ibid., at paragraph 89 .

${ }^{164}$ Ibid., at paragraph 101 .
} 
first objective with which all administrators must formally engage in before resorting to any others. ${ }^{165}$ The Court of Appeal has therefore solidified the approach to TUPE and administrations, firmly applying an absolutist approach as it has the merit of achieving legal certainty: all involved will know where they stand upon the appointment of an administrator. ${ }^{166}$

60 The very fact that there has been such a long and arduous task of settling on the criteria upon which the insolvency exception would apply is exemplary of another important fundamental difference between the UK and France. The common law of the UK gives priority to the findings of judges and applies the principle of stare decisis, giving judicial decisions a legislative function through the adherence to precedent. The French civil law system, however, adheres to general principles of the law and a more strict separation of powers. A judge's interpretation in the UK is used to create legal rules, which in a civil law system is a function solely ascribed to the legislator. ${ }^{167}$ Judges in civil jurisdictions, however, enjoy the authority of reason, exercising independence in their decision making from any similar cases which may have come before. ${ }^{168}$ As such, decisions in France may not always follow the exact same line of reasoning, depending on the case before them, but the same rule of law will habitually be applied. The functional differences in the legal systems, which apply not only to France and the UK, are another obstacle that continues to prevent convergence.

\section{The Current Position}

61 The basic position in the UK is that where proceedings are instigated with a view to resolving financial difficulty rather than liquidating the assets of the company, the employees of that company retain their acquired rights and transfer to any purchaser. ${ }^{169}$ The foregoing UK cases have entrenched this position in domestic law, with the effect that in any business sale by a company in administration, employees will automatically transfer to the buyer of that business. According to the Court, due to its very nature, administration proceedings can never be instituted with a view ${ }^{170}$ to liquidation, ${ }^{171}$ so TUPE will always apply to business transfers out of administration. This position is regarded as having a potentially serious effect on the sales of businesses out of administration unless

\footnotetext{
${ }^{165}$ Ibid., at paragraph 102.

${ }^{166}$ Ibid., at paragraph 103

${ }^{167}$ See W. Tetley QC, "Mixed Jurisdictions: Common Law vs Civil Law (Codified and Uncodified)" (1999) Uniform Law Review (N.S.), at 21.

168 Ibid., at 22.

${ }^{169}$ Barnard, above note 104; Derbyshire and Hardy, above note 147, at 57-58.

${ }^{170}$ Emphasis added by author.

171 See Anon. "Transfer of Undertakings - No Exemption for Administrations" (2011) 94 Technical Bulletin, section 94.8 .
} 
further jurisprudence or legislative amendment provides otherwise. ${ }^{172} \mathrm{~A}$ consultation on TUPE was recently undertaken in the UK but its focus was not on the effect of TUPE in business rescues situations and has suggested few changes that will affect its application in corporate rescue procedures. ${ }^{173}$

62 The consequences for business rescue could be significant in relation to the outcome of transfer negotiations as the net value of the business will be reduced as a reflection of the increased risk exposure associated with transferring employees. ${ }^{174}$ A survey performed in the UK by R3 in $2011^{175}$ was taken among 379 R3 members and showed that over $50 \%$ of insolvency practitioners have dealt with cases in a 12 month period where a buyer has either withdrawn or discounted its purchase price as a result of TUPE liability. $40 \%$ had seen cases where the purchaser had entered liquidation rather than being sold as a going concern as a result of buyers not wishing to take the financial risks associated with employee contracts. A further two thirds responded to a general query that the purchaser had withdrawn or reduced their purchase bid due to the impact of TUPE while the 1/3 remaining replied that liquidation was a consequence of the impact of TUPE. ${ }^{176}$

63 France had a provision for contractual acquired rights in place well before the ARD was introduced. The EU social policy position was in fact influenced by what already existed in French law. Thus France has not suffered a resistance to acquired rights given that the concept was born in that jurisdiction. It is interesting to note, however, that in the more recent reforms, France has chosen to relieve the burden of employment liabilities for certain of their corporate rescue procedures, while the most recent decrees have added additional consultation and information burdens. The UK, however, continues to struggle with its implementation of the ARD in relation to its effect on corporate rescue. Its application is, in fact, one of the more onerous in the EU.

64 Considering the amount of cross-border business and the insolvencies which have occurred during the financial crisis, a diversity of approaches to employment protection is not necessarily a benefit as it confuses the process by allowing employees of the same company to be treated differently if in different jurisdictions. However, little has been done to try to harmonise approaches due to the resistance of member states to the interference of the EU in matters of national

\footnotetext{
172 See C. Fallon, “Employment: Sales of Insolvent Businesses - Employees Transfer or Not?” (May 2011) Corporate Briefing 6.

173 Department of Business Innovation and Skills, Consultation on the Transfer of Undertakings (Protection of Employment) Regulations 2006, copy available at: <https://www.gov.uk/government/consultations/transfer-of-undertakings-protection-of-employmentregulations-tupe-2006-consultation-on-proposed-changes> (last accessed 15 June 2014).

${ }^{174}$ See S. Horne, "From a Question of Fact to An Absolute Rule" (2011) Employment Law Journal 2.

175 The Association of Business and Recovery, the leading organisation for insolvency, restructuring and turnaround specialists in the UK.

${ }^{176}$ See A. Stephens and G. Palfrey, "TUPE and the Current State of Play" (2012 Autumn) Recovery 22.
} 
social policy. While coordination in insolvency has been a long process, it has reached a far more equitable space within the EIR that which currently exists for ARD implementation and, indeed, labour regulation generally.

\section{EU Coordination and Convergence}

\section{Lack of Social Coordination}

65 The EIR in its current state leaves the governance of employee contracts affected by business transfers solely to the applicable law of the Member state. The proposed amendments to the EIR retain the same wording and intent but propose an additional provision in relation to acquired rights. INSOL Europe has recommended the inclusion of a second paragraph to the "Contracts of Employment" Article 10 of the Insolvency Regulation which clarifies the legal jurisdiction governing employment contracts affected by business transfers occurring under secondary proceedings. The inclusion of this paragraph is aimed at addressing the fact that different jurisdictions have different approaches to insolvent business transfers and acquired rights owing to the derogation available under the ARD. In acknowledging these different approaches and provisioning for them, INSOL Europe's proposals fail to assist in resolving the broader issue of equalising the application of acquired rights in cross-border corporate rescue procedures, though admittedly this did not feature as an intention of the proposals. In addition, the discussions of upcoming reforms by EU institutions and related commentary also do not appear to consider the application of acquired rights together with reforms to the EIR.

66 The wide divergence of the application of acquired rights in business transfer situations creates an opportunity for another species of forum shopping. The differences in the systems in terms of transferability of employees could become a consideration in the choices made when group companies find themselves in financial difficulty and must choose to close down or sell off certain parts of their operation throughout the EU. As the EIR is intended to reduce the ease with which insolvent companies can engage in forum shopping, it is reasonable to consider how diverse approaches to the ARD may influence the efficiency of cross-border corporate rescue procedures within the EU.

67 The diversity of employment entitlements across the EU can affect the choices businesses make when deciding where to invest or divest. In those jurisdictions where employment regulation is more flexible, companies may develop labour intensive businesses to take advantage of the ease of changing employment contracts, dismissing employees, paying less in wages and social security. It may also be easier to shut down those businesses in times of financial difficulty. ${ }^{177}$

\footnotetext{
${ }^{177}$ Bieback, above note 116 , at 926 .
} 
Flexible employment protection facilitates capricious investment and could potentially create greater instability in economies because businesses are able to come and go with greater ease. ${ }^{178}$ This also affects communities where businesses are dissolved as it will lead to fluctuating levels of unemployment, placing a greater dependence on State social security systems.

68 If one considers choice of investment and divestment in different jurisdictions, economics with more flexibility in the labour market are likely to remain more volatile places for job security ${ }^{179}$ as well as for the maintenance of business integrity. The dissonance of applications of acquired rights interferes with this goal in so far as different jurisdictions will continue to attract different varieties of investment depending on the legal climate. It may therefore be reasonable to consider methods of coordination or convergence in this area in order to bring it into line with what is already present within the EIR and its forthcoming reforms.

\section{Seeking Convergence or Harmonisation}

69 While there are a number of arguments that individual states have made against harmonisation of social policy within the EU, there are also many arguments that support such action. Globalisation has made it possible for capital to relocate to jurisdictions which provide the most beneficial legal regimes in order to maximise profitable opportunities, as is evident with the utilisation of social dumping and the shifting of COMI under the EIR in order to gain the best advantage in insolvency procedures. A consequence of the mobility of capital is the need for individual nations to tailor their economies in order to attract and retain capital investment. The question arises as to why any kind of employment protection is necessary if the otherwise free play of market forces allow capital investment to side step protective efforts to invest elsewhere. In such a case, it could be argued that it makes more sense to craft employment law to serve the needs of business so that national companies can compete on a global stage. However, this argument ignores the fact that labour is not just a commoditised factor of production. In addition, the presence of EU social policy requires a certain level of investment in social protection, which makes competitive labour regulation impossible within the current framework, particularly in this case given the EU wide application of the ARD. ${ }^{180}$ The answer may be to entrench specific labour rights and protections associated with cross-border insolvency within the EIR itself in order to create a balance between jurisdictions for an overall convergent insolvency system. ${ }^{181}$

\footnotetext{
178 See A. Cuñat and M. J. Melitz, "Volatility, Labour Market Flexibility, and the Pattern of Comparative Advantage" (2007) National Bureau of Economic Research Working Paper 13062.

${ }^{179}$ Idem

180 See R. Dukes, “Constitutionalizing Employment Relations: Sinzheimer, Kahn-Freund, and the Role of Labour Law” (2008) 35(3) Journal of Law and Society 341, at 341-342.

${ }^{181}$ See B. Hepple, "New Approaches to International Labour Regulation" (1997) 26(4) Industrial Law Journal 353, at 355 .
} 
70 Competition continues to be a fuel which feeds investment choices and employment regulation plays an important role as a competitive force. Employers in one state gain advantages if labour and social laws permit them to engage in employment practices below the essential standards required in others. The EU approach to labour regulation in terms of requiring minimum standards of social protection fails to equalise the playing field. In order to equilibrate the competitive landscape within the EU, a broad equivalence in labour standards would be required. ${ }^{182}$ A reasonable starting point might be the relationship between corporate rescue and the ARD. The problem with this approach is that each system begins from a different perception with different aims and methods regarding social legislation and corporate rescue, both on a national level and under EU social policy legislation.

71 The question remains, then, as to whether harmonisation would provide adequate benefits to justify the upheaval it would cause. One argument against harmonisation is that it would restrict the benefits which could flow from economic integration in the form of opening up and extending the market. Convergence of standards to a median level of protection between national systems at different stages of economic development would remove an individual comparative advantage from those states with lower social costs. Thus harmonisation potentially becomes a form of protectionism imposed by more developed economic systems for their own benefit. ${ }^{183}$ However, if one compares the two developed systems of the UK and France, the differences between them undermine this argument. Under the EU treaties it was agreed that harmonisation should be made possible by convergence and the approximation of laws within the single free EU Common Market. Free movement of people and capital should favour harmonisation as should the approximation of provisions laid down by EU law in regulatory or administrative form. ${ }^{184}$ As such, the idea that it may be unfair to force the lowering or raising of standards to meet some common level among member states is moot. EU membership itself precludes individual Member state pursuit of competitive advantages which cause imbalances in the Common Market. Unfortunately, the pursuit of harmonisation continues to encounter obstacles associated with jurisdictional factors relating to history, economy, society, culture and the idiosyncratic manner in which legal systems evolved in different jurisdictions. Politics also plays a heavily obstructionist role to aims of convergence.

\footnotetext{
${ }^{182}$ See Lord Wedderburn of Charlton, "The Social Charter in Britain: Labour Law and Labour Courts?" (1991) 54(1) Modern Law Review 1, at 16.

183 See S. Deakin and F. Wilkinson, "Rights vs Efficiency? The Economic Case for Transnational Labour Standards" (1994) 23(4) Industrial Law Journal 289, at 289.

184 "Treaties of Rome" on Eurofound, copy available at:

<http://www.eurofound.europa.eu/areas/industrialrelations/dictionary/definitions/treatiesofrome.htm> (last accessed 15 June 2014).
} 
Conclusion: Harmony or Dissonance?

72 The EU Treaties have so far left the competence to regulate social policy to the member states. ${ }^{185}$ Even when drafting the first Treaties in the 1950s it was mainly France that sought to give more power to the European Economic Community in the field of social policy so that it might raise the level of protection in other member states to a level more equal to the system in France. ${ }^{186}$ However, the tension between the goal of harmonisation of social policy and the aim of the free market has made this difficult if not impossible. ${ }^{187}$

73 There are few Regulations in the EU which deal with social policy issues; most social policy rules are legislated through Directives which are only binding on states as to the results to be achieved. The member states then have reasonable latitude to implement them through the means and methods that they see fit, often taking advantage of exclusions and caveats which not all member states will apply. ${ }^{188}$ As such, the European Employment Strategy has seen diverse implementation among the member states as a result of a gap between the EU level aims and national policies. ${ }^{189}$ While recently the importance of social policy has been strengthening in the EU, it remains a fractured subject among the member states which will not be easy to coordinate.

74 The differences in labour flexibility among the states of the EU can cause instability in a jurisdiction and may arise to some degree where the application of employee acquired rights in business rescue is not so strict. This may also be an argument for the harmonisation of labour laws across the EU generally. In order to avoid this species of social dumping, it may be necessary to remove distortions in competition, such as flexible versus inflexible labour regulation in this case. While most descriptions of social dumping indicate undervalued labour in the sense that employees are paid lower wages and have less employment rights, ${ }^{190}$ it is reasonable that this concept could be applied to the rights of employees on business transfers as this also has an effect on the cost of doing business in a jurisdiction. As mentioned in the R3 report cited above, this can lead to a reduction in the price for a business transfer, the failure of a deal and potentially the failure of a rescue initiative, leading to liquidation and a far more debilitating loss of employment security.

\footnotetext{
${ }^{185}$ Bieback, above note 116 , at 916 .

186 Ibid., at 913 .

187 See C. Barnard and S. Deakin, "Negative and Positive Harmonisation of Labour Law in the European Union” (2002) 8 Columbia Journal of European Law 389, at 389.

188 See G. Barrett, "Deploying the 'Classic Community Method' in the Social Policy Field: The Example of the Acquired Rights Directive” (2009) 15(2) European Law Journal 198, at 198.

${ }^{189}$ Kettunen and Wolff, above note 99, at 145.

${ }^{190}$ See B. Hepple, Labour Laws and Global Trade (2005, Hart Publishing, Portland OR), at 14.
} 
75 As the future sees the slow meeting of minds among the European countries in relation to business orientated legislation under the umbrella of EU law such as the EIR, the position on social policy remains static and continues to vary quite widely between jurisdictions, as evidenced by the different approaches to the ARD in the UK and France and the fundamental differences that influence those approaches. The creation of the Common Market was intended to foster trading across national boundaries and a functioning bankruptcy system forms a part of legal regime needed to support the market. ${ }^{191}$ While the reasons why a similar treatment has not been given to labour regulation are myriad, there remains an argument that an equalisation across the member states might be best for all. Such a balancing could have the effect of fostering greater stability across the EU and certainly in individual member states whose legal regimes vary greatly. A starting point could be the focussed intersection of insolvency and employment protection within the ARD and its implementation throughout the EU member states. Given the advantages to the rescue culture that could be gained through the harmonisation of transfer of undertakings provisions in insolvency, it might not meet with the same level of resistance as other more emotive areas of social policy. If it were possible to apply harmonisation principles to this specific area, it could act as a template for further convergence in the area of social policy in the EU.

\footnotetext{
${ }^{191}$ Omar, above note 2, at 49.
} 
[this page is intentionally blank] 